Gulawentah: Jurnal Studi Sosial

ISSN 2528-6293 (Print); ISSN 2528-6871 (Online)

Vol. 4, No. 2, Desember 2019, Hal 74-77

Tersedia Online: http://e-journal.unipma.ac.id/index.php/gulawentah

\title{
Pengembangan Media Pembelajaran Ekonomi Interaktif Berbasis Android Sebagai Upaya Peningkatan Aktivitas dan Hasil Belajar Siswa
}

\author{
Hari Nur Wahyono \\ Madrasah Aliyah Negeri 1 Ngawi, Jalan Jekitut 688 Ngawi, Kabupaten Ngawi, Indonesia \\ Email: harinurwahyono@gmail.com
}

\begin{abstract}
Abstrak
Penelitian ini bertujuan untuk (1) mengembangkan media pembelajaran ekonomi berbasis Android pada materi akuntansi; (2) mendiskripsikan keaktifan belajar siswa melalui media pembelajaran interaktif berbasis android; serta (3) mendiskripsikan prestasi belajar siswa yang menggunakan media pembelajaran android dan yang tidak menggunakan. Penelitian ini menggunakan penilitian dan pengembangan (research and development) yang berarti penelitan ini merupakan penelitian yang berorientasi pada produk.dengan mengadaptasi 4D dari Thiagarajan dengan tahap-tahap pendefinisian, perencanaan, pengembangan, dan penyebaran. Modifikasi yang dilakukan adalah pendefinisian, perencanaan, dan pengembangan.
\end{abstract}

Kata kunci: Media Pembelajaran Ekonomi, Berbasis Adroid; Aktivitas Siswa; Hasil Belajar

\section{Development of Interactive Economy Learning Media Based on Android as an Effort to Increase Student Activities and Learning Outcomes}

\begin{abstract}
This study aims (1) to develop an Android-based economic learning media on accounting material; (2) to describe students' learning activity through interactive android based learning media; and (3) to describe student's learning achievement using android learning media and those who do not use. This research uses research and development, which means this research is product oriented research by adapting $4 D$ from Thiagarajan with stages of defining, planning, developing, and disseminating. Modifications made are defining, planning, and developing.
\end{abstract}

Keywords: Economic Learning Media, Based on Adroid; Student Activities; Learning outcomes

\section{Pendahuluan}

Dunia pendidikan saat ini semakin berkembang, berbagai macam pembaharuan dilakukan agar dapat meningkatkan kualitas dan kuantitas pendidikan. Untuk meningkatkan kualitas pendidikan diperlukan berbagai terobosan, baik dalam pengembangan kurikulum, inovasi pembelajaran, dan pemenuhan sarana serta prasarana pendidikan. Untuk meningkatkan prestasi belajar siswa, maka guru dituntut untuk membuat pembelajaran menjadi lebih inovatif yang mendorong siswa dapat belajar secara optimal baik di dalam belajar mandiri maupun dalam pempelajaran di kelas.

Siswa banyak menggunakan smartphone untuk bermain games dan media sosial, ini akan mengganggu belajar mereka, karena konsentrasinya akan berkurang atau menurun. Siswa lebih fokus untuk melihat smartphone, bahkan sampai kecanduan smartphone (Astuti, Sumarni, \&

DOI: 10.25273/gulawentah.v4i2.5522

Copyright (C) 2019 Universitas PGRI Madiun

All rights reserved. 
Saraswati, 2017). Inovasi model-model pembelajaran sangat diperlukan dan sangat mendesak terutama dalam menghasilkan model pembelajaran baru yang dapat memberikan hasil belajar lebih baik, peningkatan efisiensi dan efektivitas pembelajaran menuju pembaharuan. Usaha untuk mencapai tujuan proses belajar mengajar dipengaruhi beberapa faktor. Faktor yang pertama adalah peserta didik itu sendiri, pengajar (guru), fasilitas, lingkungan, media pendidikan serta metode pembelajaran yang digunakan. Media pembelajaran harus dikemas semenarik mungkin agar siswa bisa berlama-lama mempelajari suatu materi (Oktiana, 2015).

Penggunaan teknologi informasi dan komunikasi di dalam dunia pendidikan terus berkembang dengan berbagai macam strategi pada dasarnya dapat dikelompokkan ke dalam sistem Electronic Learning (E-Learning) sebagai bentuk pembelajaran dengan memanfaatkan media digital (Putra \& Nugroho, 2016). Istilah mobile learning pula dapat dikatakan sebagai bentuk pembelajaran yang memanfaatkan perangkat dan teknologi bergerak. Mobile Learning ( $M$ Learning) adalah pengembangan dari E-Learning. Istilah mobile learning mengacu kepada perangkat IT genggam dan bergerak dapat berupa PDA (Personal Digital Assistant), telepon seluler, laptop, tablet PC, dan sebagainya. Mobile learning dapat memudahkan pengguna untuk mengakses konten pembelajaran di mana saja dan kapan saja, tanpa harus mengunjungi suatu tempat tertentu pada waktu tertentu. "Mobile learning berhubungan dengan mobilitas belajar. Menurut (Anam, 2017; Izzati \& Sumarsih, 2017) pembelajaran akuntansi dengan menggunakan multimedia dapat membantu siswa dalam peningkatan penguasan materi.

Permasalahan yang timbul dalam penelitian pengembangan media pembelajaran ini adalah, (1) Bagaimana proses mengembangkan media pembelajaran interaktif berbasis Android menggunakan aplikasi PhoneGap pada materi Akuntansi sebagai Sistem Informasi dan Persamaan dasar Akuntansi serta; (2) Bagaimana keaktifan belajar siswa melalui media pembelajaran interaktif berbasis android dan (3) Bagaimana prestasi belajar siswa yang menggunakan media pembelajaran android dan yang tidak menggunakan media pembelajaran yang berbasis android.

\section{Metode Penelitian}

Metode Penelitian yang digunakan untuk mengembangkan media pembelajaran berbasis android dalam penelitian ini adalah modifikasi dari 4D dari Thiagarajan dengan tahap-tahap pendefinisian, perencanaan, pengembangan, dan penyebaran, modifikasi yang dilakukan adalah tidak dilakukanya tahap penyebaran (Setyosari, 2016). Waktu penelitian dilakukan bulan Januari sampai dengan Februari. Subjek Penelitian terdiri atas subjek validasi media dan subjek uji coba. Subjek validasi media meliputi satu orang ahli materi dan satu orang ahli media, dan 3 orang pendidik Ekonomi Madrasah Aliyah. Uji coba produk terdiri atas uji coba perorangan, uji coba terbatas, dan uji coba lapangan. Subjek uji coba perorangan terdiri atas 9 peserta didik kelas XII IIS, sedangkan subjek uji coba terbatas meliputi 31 peserta didik SMA kelas XII IIS. Subjek uji coba lapangan merupakan peserta didik Madrasah Aliyah kelas XII IIS dengan rincian 34 peserta didik pada kelas eksperimen dan 36 peserta didik pada kelas kontrol. Pengumpulan data pada penelitian ini menggunakan instrumen validasi media dan instrumen uji coba. Instrumen validasi media terdiri atas (1) lembar validasi media untuk ahli media pembelajaran, (2) lembar validasi materi untuk ahli materi, serta (3) lembar penilaian kualitas media. Instrumen uji coba terdiri atas (1) lembar penilaian kualitas media pembelajaran oleh peserta didik (digunakan pada uji coba perorangan dan uji coba terbatas), (2) soal tes hasil belajar kognitif (digunakan pada uji lapangan). Seluruh instrumen divalidasi oleh ahli secara konstruk dan konten. Instrumen tes hasil belajar kognitif berupa soal pilihan ganda divalidasi oleh ahli dan juga divalidasi secara empirik. Uji coba lapangan dilakukan untuk mengetahui pengaruh penggunaan media pembelajaran yang dikembangkan terhadap performa akademik Peserta didik Desain uji coba yang di gunakan berupa Prestest-Posttest. 


\section{Hasil dan Pembahasan}

Pengembangan media mobile learning berbasis aplikasi android adalah suatu proses pembuatan media pembelajaran dari belum ada sampai menjadi hasil sebuah media pembelajaran, aplikasi dapat dioperasikan pada smarpthone khususnya android. Proses pengembangan ini bertujuan untuk membantu siswa memahami lebih dalam materi ekonomi akuntansi karena keterbatasannya waktu di sekolah sehingga media ini termasuk media belajar mandiri tanpa harus terikat waktu dan ruang serta menjadi suatu sumber alternatif bagi siswa untuk memahami materi ekonomi akuntansi kapanpun dan di manapun. Kegiatan penelitian ini di lakukan di Madrasah Aliyah Negeri 1 Ngawi di kelas XII IIS. Pengembangan media pembelajaran tersebut dapat di deskripsikan sebagai berikut: tahap pertama pendefinisian (Define), tahap ini menganalisis kondisi guru dan siswa dalam problem dan kebutuhan pembelajaran. Tahap kedua Perancangan (Design) setelah menganalisa dan pengumpulan data, tahap perancangan ini tahapan yang dilakukan adalah pembuatan Rencana Pelaksanaan Pembelajaran (RPP), Pembuatan layout media pembelajaran, serta angket. Tahap ketiga Pengembangan Draf Produk (Develop) pada tahap ini peneliti memasukan seluruh materi ke aplikasi Phonegap melalui proses pencodingan lewat komputer. Seluruh perangkat dan media pembelajaran yang telah dibuat di validasi oleh Ahlinya di bidangnya masing-masing. Hasil Penelitian menunjukan bahwa aktivitas siswa pembelajaran menggunakan media pembelajaran Interaktif Android di respon positif oleh siswa dan mengalami peningkatan aktivitasnya di banding dengan tanpa menggunakan media pembelajaran.

Tabel 1. Aktivitas Siswa

\begin{tabular}{llllll}
\hline & \multicolumn{4}{c}{$\begin{array}{c}\text { Aktivitas Siswa dalam } \\
\text { Kategori Pengamatan }\end{array}$} & \multicolumn{3}{c}{ Pertemuan ke- } & \multirow{2}{*}{$\begin{array}{c}\text { Kriteria Batasan } \\
\text { Efektif (\%) }\end{array}$} \\
\cline { 2 - 4 } & 1 & 2 & 3 & 4 & \\
\hline $\begin{array}{l}\text { Memperhatikan/mendengarkan } \\
\text { penjelasan guru/teman }\end{array}$ & 23,33 & 24,44 & 21,11 & 26,67 & $21 \%-31 \%$ \\
\hline $\begin{array}{l}\text { Membaca/memahami masalah } \\
\text { kontekstual dalam buku } \\
\text { siswa/LKS }\end{array}$ & 11,11 & 14,44 & 15,56 & 13,33 & $6 \%-16 \%$ \\
\hline $\begin{array}{l}\text { Menyelesaikan masalah/ } \\
\text { menemukan cara dan jawaban } \\
\text { masalah. }\end{array}$ & 42,22 & 42,22 & 43,33 & 44,44 & $39 \%-49 \%$ \\
\hline $\begin{array}{l}\text { Berdiskusi/bertanya kepada } \\
\text { teman atau guru }\end{array}$ & 11,11 & 10,00 & 10,10 & 6,67 & $6 \%-16 \%$ \\
\hline $\begin{array}{l}\text { Menarik kesimpulan suatu } \\
\text { Prosedur dan Konsep }\end{array}$ & 10,00 & 6,67 & 7,75 & 6,67 & $3 \%-13 \%$ \\
\hline $\begin{array}{l}\text { Perilaku yang tidak relevan } \\
\text { dengan KBM }\end{array}$ & 2,22 & 2,22 & 2,22 & 2,22 & $0 \%-5 \%$ \\
\hline
\end{tabular}

Tingkat efektivitas pembelajaran dapat dilihat dari perbedaan rerata kelas, dimana diperoleh rata-rata nilai kelas eksperimen 81,37 dan nilai kelas kontrol 74,55. Dari segi daya tarik pembelajaran ekonomi menggunakan media pembelajaran interkatif berbasis Android daya tarik yang tinggi dengan bukti di respon positif oleh siswa di atas $80 \%$. Prestasi belajar siswa yang menggunakan media pembelajaran Android lebih baik di banding dengan siswa yang tidak menggunakan media pembelajaran interkatif berbasis Android, hal ini dapat dilihat dari hasil yang diperoleh rata-rata nilai kelas eksperimen yang menggunakan media pembelajaran sebesar 81,37 dan kelas kontrol yang tidak menggunakan media pembelajaran mendapatkan nilai 74,55. 


\section{Simpulan}

Proses pengembangan media pembelajaran interaktif berbasis Android dilakukan dengan menggunakan prosedur pengembangan yang adopsi dari model 4D yang telah di modifikasi menjadi 3 tahap yaitu Pendifinisian, Perencanaan, Pengembangan. Kegiatan pengembangan yang telah dilakukan menggunakan prosedur ini menghasilkan media pembelajaran interaktif berbasis Android yang valid dan layak digunakan oleh siswa kelas XII IIS Madrasah Aliyah Negeri Ngawi pada mata pelajaran Ekonomi pada materi pokok Akuntansi sebagai system Informasi dan persamaan dasar akuntansi. Pembelajaran Ekonomi pada kelas yang menggunakan media pembelajaran Interaktif berbasis Android lebih efektif di bandingkan kelas yang tidak menggunakan media pembelajaran interaktif yang berbasis Android .

\section{Daftar Pustaka}

Anam, C. (2017). Pengembangan Mobile Learning Berbasis Android Sebagai Media Pembelajaran Pada Materi Akuntansi Kas. Jurnal Pendidikan Akuntansi (JPAK), 5(3).

Astuti, I. A. D., Sumarni, R. A., \& Saraswati, D. L. (2017). Pengembangan Media Pembelajaran Fisika Mobile Learning berbasis Android. Jurnal Penelitian \& Pengembangan Pendidikan Fisika, 3(1), 57-62.

Izzati, F. D., \& Sumarsih, S. (2017). Pengembangan Media Pembelajaran Aplikasi Peta Akuntansi (TAKSI) Berbasis Android pada Materi Siklus Akuntansi Perusahaan Jasa. Jurnal Pendidikan Akuntansi Indonesia, 15(2).

Oktiana, G. D. (2015). Pengembangan media pembelajaran berbasis android Dalam bentuk buku saku digital untuk mata pelajaran Akuntansi kompetensi dasar membuat ikhtisar siklus Akuntansi perusahaan jasa di kelas xi man 1 Yogyakarta tahun ajaran 2014/2015. Skripsi tidak diterbitkan (online). Yogyakarta: Jurusan Pendidikan Akuntansi Universitas Negeri Yogyakarta.

Putra, D. R., \& Nugroho, M. A. (2016). Pengembangan Game Edukatif Berbasis Android Sebagai Media Pembelajaran Akuntansi Pada Materi Jurnal Penyesuaian Perusahan Jasa. Jurnal Pendidikan Akuntansi Indonesia, 14(1).

Setyosari, H. P. (2016). Metode penelitian pendidikan \& pengembangan: Prenada Media. 